\title{
Risk factors for meningococcal meningitis in northern Ghana
}

\author{
Abraham Hodgson ${ }^{1}$, Thomas Smith ${ }^{2}$, Sebastien Gagneux ${ }^{1,2}$, Martin Adjuik ${ }^{1}$ Gerd Pluschke ${ }^{2}$, \\ Nathan Kumasenu Mensah', Fred Binka ${ }^{1}$ and Blaise Genton ${ }^{2}{ }^{\prime}$ Navrongo Health Research Centre, Ministry of \\ Health, Ghana; ${ }^{2}$ Swiss Tropical Institute, Basel, Switzerland
}

\begin{abstract}
Meningococcal meningitis is a major cause of morbidity and mortality in the meningitis belt of subSaharan Africa where it occurs in epidemics every 8-12 years. Risk factors for the disease in this setting remain largely unknown. We carried out a case-control study to investigate possible risk factors among survivors of a meningitis epidemic occurring in 1997 in northern Ghana. A structured questionnaire on socio-economic factors, housing and household overcrowding, smoking and exposure to smoke and close contact with a case was administered to 505 of the survivors and 505 of age-, sex- and location-matched controls. Cooking in kitchens with firewood stoves (OR 9.00, CI 1.25-395) and sharing a bedroom with a case (OR $2 \cdot 18 \mathrm{CI} 1.43-3 \cdot 4$ ) were found to be risk factors for disease. Socio-economic factors, overcrowding, smoking and passive exposure to tobacco smoke were not found to be risk factors. Exposure to smoke from cooking fires or close contact with a case puts people at risk of contracting meningococcal meningitis. In the hot dry months, exposure to smoke from cooking fires should be minimized by encouraging alternatives to cooking over wood fires, or cooking outside. If wood-burning stoves cannot be avoided, kitchens should be made larger with improved ventilation. Meningitis cases should be nursed in well-ventilated rooms and the number of people sharing a room with a case kept at a minimum.
\end{abstract}

Keywords: meningitis, Neisseria meningitidis, risk factors, smoke, contact, Ghana

\section{Introduction}

At least 1.2 million cases of bacterial meningitis are estimated by the World Health Organization (WHO) to occur every year with 135000 deaths. About 500000 of these cases and 50000 of these deaths are due to Neisseria meningitidis (TIKHOMIROV et al., 1997). The highest incidence is in a belt across Africa stretching from Senegal to Ethiopia. In this belt, large epidemics of meningococcal disease occur every 8-12 years, during which attack rates may exceed 500 per 100000 population (TIKHOMIROV et al., 1997).

The reasons for these epidemics are not fully understood although a complex combination of host, organism and environmental risk factors appears to be involved (MOORE, 1992). Climatic factors clearly play an important role since epidemics nearly always start in the dry season when it is hot and dusty and subside during the rains (GREENwood et al., 1985). Low humidity, high temperature and dust might enhance meningococcal invasiveness by directly damaging the mucosal barrier or by inhibiting mucosal immune defences (MOORE, 1992). Apart from these factors being very difficult to modulate as a means of controlling future epidemics, it is observed that not everyone exposed to the causal agent during these epidemics develops disease.

Risk factors for meningococcal disease in industrialized countries include overcrowding (STANWELLSMITH et al., 1994), passive exposure to tobacco smoke (HANEBERG et al., 1983; STANWELL-SMITH et al., 1994; FISCHER et al., 1997), kisses on the mouth (STANWELL-SMITH et al., 1994), preceding respiratory infections (CARTWRIGHT et al., 1991; HARRISON et al., 1991), dust exposure (STANWELL-SMITH et al., 1994), and strcss (HANEBERG et al., 1983; STANWELL-SMITH et al., 1994).

There have been few studies of risk factors in Africa, although the distinct epidemiological pattern suggests that the factors precipitating clinical episodes may differ from those found in industrialized countries. GREENWOOD et al. (1987) found that socio-economic status, crowding and nutrition, were not important factors influencing susceptibility to group A meningo-

Address for correspondence: Dr Blaise Genton, Swiss Tropical Institute, Socinstrasse 57, CH-4002, Basel, Switzerland; phone +41612848130 , fax +41612718654 ,

e-mail blaise.genton@hospvd.ch coccal disease during an epidemic in The Gambia. In Kenya, the highest attack rates were recorded in slum areas of Nairobi (PINNER et al., 1992). In northern Nigeria, epidemic meningococcal disease was less frequent among the upper social classes (GREENWOOD et al., 1979).

In the Kassena-Nankana district of northern Ghana there was a meningitis epidemic in 1997 in which 1396 cases with 65 deaths were recorded at the district hospital and 3 health centres (ENOS, 1997). Bacteriological analysis of samples from a resurgence of the epidemic the following dry season indicated that the causal organism was $N$. meningitidis serogroup A subgroup III (GAGNEUX et al., 2000), the predominant organism of meningococcal epidemics in Africa during the 1990s. We now report a case-control study in survivors of that epidemic of risk factors for meningococcal meningitis.

\section{Methodology \\ Study area}

The Kassena-Nankana district (KND) is within the guinea savannah area of northern Ghana bordering Burkina Faso. It covers an area of $1675 \mathrm{~km}^{2}$. The entire population of the district, about 140000 , are included in a demographic surveillance system, the Navrongo Demographic Surveillance System (NDSS), in which births, deaths, in and out migrations and other demographic parameters are recorded in a database and updated every 90 days (BINKA et al., 1996).

\section{Data collection}

A list of all clinically/laboratory diagnosed meningitis cases at the district hospital during the 1997 epidemic period was compiled from the hospital records. In accordance with WHO guidelines, a case was defined by sudden onset of fever and stiff neck, or fever and stiff neck and altered mental status. Cases were traced during mid-1999 to ascertain or confirm their identification numbers in the NDSS database and their vital status. For each of these cases, the nearest eligible age$( \pm 10 \%)$ and sex-matched control, who had not suffered from meningitis and was alive in mid-1999, was selected from the NDSS. A geographical information system was used to locate the nearest eligible control to the home of the case. After informed consent had been obtained from cases, controls and their relatives, they were all transported to the hospital for interview.

A trained research assistant who was blinded to the disease status administered a structured questionnaire 
to subjects and their relatives. The questionnaire had been translated from English into the 2 local languages (and back translated), then pre-tested among survivors of the 1998 outbreak, and modified accordingly. The questionnaire was designed to collect information on education, occupation and marital status of subjects, occupation of head of household and family possessions, housing conditions and household overcrowding, contact with a case, smoking and exposure to smoke. During questionnaire administration, sensitive issues were explored only after a good relationship had been established. Confidentiality of the data obtained was assured.

Completed forms were checked for completeness and internal consistency. Data were coded and double entered into the computer using FoxPro. Matched analysis was done using standard Mantel-Haenszel methods.

\section{Results}

During the epidemic 1077 admissions were recorded: 100 proved to be re-admissions of the same individuals; $792(81 \%)$ of the 977 distinct patients could be traced; 16 of the people found denied that they had suffered from meningitis; 557 patients were found present and alive, and of these 505 were interviewed along with their matched controls [see HODGsoN et al. (2001) for details on subject recruitment and demographic characteristics].

\section{Socio-economic factors}

Educational level, employment and marital status of the subjects were not associated with meningitis (Table 1), neither was the occupation of the head of household. More controls than cases had cows, goats, sheep, cats and pigs, while more cases had donkeys, chickens, guinea fowls, ducks and dogs but these differences were generally small and none was statistically significant. Possession of a radio, which was used as one of the measures of socio-economic status, had no influence on meningitis risk.

\section{Housing conditions and household overcrowding}

The number of windows in the subject's bedroom averaged 1.2 for both cases and controls. The mean number of people in a compound was 14.9 (SD 11.8) for cases and 15.9 (SD 11.9) for controls. This corresponded to mean numbers of bedrooms of 7.2 (SD $5 \cdot 2$ ) and $7 \cdot 6(\mathrm{SD} 5 \cdot 8)$ respectively. The average number of people sleeping in the room in which the subject sleeps was 3.3 for both cases and controls. None of these differences was statistically significant (see details in Table 1).

\section{Close contact with a case}

Even though more controls than cases had a case/ another case of meningitis in their compounds [Mantel-Haenszel matched odds ratio (OR) $0 \cdot 80,95 \%$ confidence interval (CI) $0.62-1 \cdot 04, P=0.10]$, more cases $(16 \%)$ than controls $(9 \%)$ were sharing the same bedroom with that case (OR $2 \cdot 18$, CI $1 \cdot 43-3 \cdot 40$, $P<0.001)$.

\section{Smoking}

Smoking habits of cases and controls were similar: $7 \%$ of cases and controls were smokers, the mean duration of smoking being 0.8 years for both. Surprisingly, cases were less likely to have smokers in their compounds than controls $(61 \%$ and $66 \%$ respectively; OR 0.73 , CI $0.54-0.99, P=0.045$ ) (Table 1). There were no differences between the smoking habits of fathers of cases and controls aged $0-5$ years nor of the parents of cases and controls aged $0-15$ years (Table 2). None of the mothers of these children smoked. There was also

Table 1. Risk factors for meningococcal meningitis in $\mathbf{5 0 5}$ cases and $\mathbf{5 0 5}$ matched controls in the 1997 epidemic in Kassena-Nankana district, northern Ghana

\begin{tabular}{|c|c|c|c|c|}
\hline & Cases $n(\%)$ & Controls $n(\%)$ & OR $(95 \% \mathrm{CI})^{\mathrm{a}}$ & $P$-value \\
\hline $\begin{array}{l}\text { Socio-economic factors } \\
\text { No education of subject } \\
\text { Unemployment of subject } \\
\text { Unemployment of head of household } \\
\text { Subject unmarried }\end{array}$ & $\begin{array}{r}210(41 \cdot 6) \\
83(16 \cdot 4) \\
3(0 \cdot 6) \\
329(65 \cdot 1)\end{array}$ & $\begin{array}{r}222(44 \cdot 0) \\
93(18 \cdot 4) \\
3(0 \cdot 6) \\
329(65 \cdot 1)\end{array}$ & $\begin{array}{l}0.86(0.62-1.19) \\
0.80(0.51-1.24) \\
1.00(0.13-7.47) \\
1.00(0.63-1.59)\end{array}$ & $\begin{array}{l}0.38 \\
0 \cdot 34 \\
0 \cdot 68 \\
0.91\end{array}$ \\
\hline $\begin{array}{l}\text { Housing conditions (subject's bedroom) } \\
\text { Thatch roof } \\
\text { Zinc roof } \\
\text { Mud roof } \\
\text { Mud walls } \\
\text { Mud floor }\end{array}$ & $\begin{array}{r}270(53 \cdot 5) \\
175(34 \cdot 7) \\
59(11 \cdot 7) \\
477(94 \cdot 5) \\
78(15 \cdot 4)\end{array}$ & $\begin{array}{r}267(52 \cdot 9) \\
167(33 \cdot 1) \\
68(13 \cdot 5) \\
482(95 \cdot 4) \\
96(19 \cdot 0)\end{array}$ & $\begin{array}{l}1.05(0.72-1.54) \\
1.11(0.80-1.55) \\
0.64(0.32-1.25) \\
0.69(0.29-1.58) \\
0.72(0.49-1.07)\end{array}$ & $\begin{array}{l}0 \cdot 85 \\
0 \cdot 57 \\
0 \cdot 21 \\
0 \cdot 44 \\
0 \cdot 11\end{array}$ \\
\hline $\begin{array}{c}\text { Possessions } \\
\text { Radio }\end{array}$ & $419(83 \cdot 0)$ & $410(81 \cdot 2)$ & $1 \cdot 18(0 \cdot 80-1 \cdot 76)$ & 0.44 \\
\hline $\begin{array}{l}\text { Close contact with case } \\
\text { Presence of another case in compound } \\
\text { Sharing of same bedroom with case }\end{array}$ & $\begin{array}{r}225(44 \cdot 6) \\
82(16 \cdot 2)\end{array}$ & $\begin{array}{c}252(49 \cdot 9) \\
43(8 \cdot 5)\end{array}$ & $\begin{array}{l}0.80(0.62-1 \cdot 04) \\
2 \cdot 18(1.43-3 \cdot 40)\end{array}$ & $\begin{array}{l}0.10 \\
<0.001\end{array}$ \\
\hline $\begin{array}{l}\text { Smoking } \\
\text { Smoking of subject } \\
\text { Presence of smoker in compound }\end{array}$ & $\begin{array}{c}36(7 \cdot 1) \\
307(60 \cdot 8)\end{array}$ & $\begin{array}{c}35(6.9) \\
335(66 \cdot 3)\end{array}$ & $\begin{array}{l}1.07(0.49-2.32) \\
0.73(0.54-0.99)\end{array}$ & $\begin{array}{l}1 \cdot 00 \\
0.045\end{array}$ \\
\hline $\begin{array}{l}\text { Exposure to smoke from cooking fires } \\
\text { Cooking done in kitchen } \\
\text { Use of firewood stove } \\
\text { Cooking done by subject } \\
\text { Exposure to smoke from cooking fires } \\
\text { (subjective response) }\end{array}$ & $\begin{array}{l}480(95 \cdot 0) \\
472(93 \cdot 5) \\
181(35 \cdot 8) \\
204(40 \cdot 4)\end{array}$ & $\begin{array}{l}465(92 \cdot 1) \\
473(93 \cdot 7) \\
181(35 \cdot 8) \\
200(39 \cdot 6)\end{array}$ & $\begin{array}{l}1.83(1 \cdot 00-3 \cdot 46) \\
0.94(0.43-2 \cdot 02) \\
1.00(0.61-1.65) \\
1.11(0.69-1.79)\end{array}$ & $\begin{array}{l}0.05 \\
1.00 \\
0.90 \\
0.73\end{array}$ \\
\hline
\end{tabular}

${ }^{2}$ Odds ratio (95\% confidence interval): obtained from age-, sex- and location-matched analysis.

${ }^{b}$ The odds for each type of roof were calculated separately, in each case comparing with the risk associated with all other roofing types.

cThe odds for mud walls and floor were calculated relative to cement walls and floor respectively. 
Table 2. Smoke exposure for specified groups of cases and matched controls during the 1997 meningococcal meningitis epidemic in northern Ghana

\begin{tabular}{lcccc}
\hline Group & $\begin{array}{c}\text { Cases } \\
n / \text { total (\%) }\end{array}$ & $\begin{array}{c}\text { Controls } \\
n / \text { total (\%) }\end{array}$ & OR (95\% CI) & $P$-value \\
\hline Age 0-5 years and father smokes & $9 / 20(45 \cdot 0)$ & $10 / 19(52 \cdot 6)$ & $0 \cdot 80(0 \cdot 16-3 \cdot 72)$ & $1 \cdot 00$ \\
Age 0-15 years and father smokes & $76 / 201(37 \cdot 8)$ & $85 / 197(43 \cdot 1)$ & $0 \cdot 78(0 \cdot 48-1 \cdot 27)$ & $0 \cdot 35$ \\
Married woman with smoking husband & $47 / 134(35 \cdot 1)$ & $53 / 126(42 \cdot 1)$ & $0 \cdot 57(0 \cdot 29-1 \cdot 09)$ & $0 \cdot 10$ \\
Cooking with firewood stove indoors & $161 / 166(97 \cdot 0)$ & $157 / 169(92 \cdot 9)$ & $9 \cdot 00(1 \cdot 25-394 \cdot 5)$ & $0 \cdot 027$ \\
\hline
\end{tabular}

${ }^{a}$ Odds ratio ( $95 \%$ confidence interval): obtained from age-, sex- and location-matched analysis.

no difference between the smoking habits of husbands of married cases and controls (Table 2).

\section{Exposure to smoke from cooking fires}

In $480(95 \%)$ of 505 cases and $465(92 \%)$ of 505 controls, cooking was carried out in kitchens rather than outside (OR 1.83 , CI $1.00-3.46, P<0.05$ ). About equal numbers of cases and controls used firewood stoves and did the cooking themselves (Table 1). When subjects (adults) or relatives (for subjects who were children) were asked about exposure of subjects to smoke from cooking fires, $40 \%$ of both cases and controls or their relatives answered in the affirmative (Table 1). For persons who used firewood stoves and did the cooking themselves, $161(97 \%)$ of 166 cases cooked in kitchens as compared to $157(93 \%)$ of 169 controls (OR 9.00, CI 1.25-395, $P=0.027$ ) (Table 2).

\section{Discussion}

A number of studies have shown associations between meningococcal disease and either smoking (FISCHER et al., 1997; COOKSON et al., 1998) or passive exposure to tobacco smoke (HANEBERG et al., 1983; STANWELL-SMITH et al., 1994; FISCHER et al., 1997; CoOKSON et al., 1998). We could not find such a direct association, probably because smoking per se is a relatively small contributor to smoke exposure in Kassena-Nankana. In the study area, few people smoke, and smoking is usually carried out outside, where the degree of passive exposure by children and wives of smokers is minimized. However, exposure to smoke from cooking fires is frequent and is a major risk factor.

The traditional kitchen in the study area is a small hut with a typical height less than that of an average man and roofed with either mud or heaps of millet stalks that also serve as fuel. Many of these structures have a small doorway through which one has to stoop to enter the kitchen, with either no window or a small hole for a window. There are no chimneys. Cooking in them using firewood stoves exposes people to very high levels of smoke. This exposure is likely to cause direct damage to the nasopharyngeal mucosa (CARTWRIGHT, 1995) where the organism is carried, resulting in tissue invasion and disease.

Household contacts of patients with meningococcal disease have been documented to have a risk of acquiring infection of about $600-1000$ times the age-specific incidence in the general population (TIKHOMIROV et al., 1997). Close contact with a case (i.e., sharing a bedroom) was also found to be a risk factor in our study, although the association was not as strong as in the previous studies. On the other hand, the presence of a case in a compound was not significantly associated with disease.

In industrialized countries, crowding (STANWELLSMITH et al., 1994; MOODLEY et al., 1999) and low socio-economic status (e.g., SALMI et al., 1976) are risk factors. However, in Kassena-Nankana, as in The Gambia (GREENWOOD et al., 1987), neither housing conditions, nor overcrowding, nor other socio-economic factors could explain why some people became ill and others did not. This is very likely to be because there were only small variations in these variables in the study population, among whom extreme poverty is almost universal.

In summary, exposure to smoke from cooking fires and close contact with a case were found to be risk factors for meningococcal meningitis. Practices that expose people to smoke, for example the usc of fucl wood in poorly ventilated kitchens, should be discouraged especially in the hot dry months. Where the use of wood-burning stoves cannot be avoided, cooking in the open should be encouraged. Modification of the construction of kitchens to improve ventilation and the use of other types of fuel might also reduce meningitis risk.

Cases should be nursed in well-ventilated rooms and the number of people sharing a room with a case be kept at a minimum. Although prophylactic treatment of close contacts of cases with rifampicin may be effective in reducing the occurrence of disease, this policy cannot be encouraged during epidemics in the African meningitis belt since it may divert effort from the prompt implementation of a mass vaccination programme.

\section{Acknowledgements}

We acknowledge the willing participation of the subjects and their relatives in the study. Technical assistance by $I$. Akumah, E. Awine, P. Adongo, P. Wontuo, S. Owusu-Agyei, D. Abanimi and G. Avogo is greatly appreciated. Professor Marcel Tanner, Dr Alex Nazzar and Dr Kweku Enos ensured excellent institutional support. The study was financed by the Meningitis Research Foundation and had ethical approval from the Ghana Ministry of Health.

\section{References}

Binka, F. N., Kubaje, A., Adjuik, M., Williams, L. A., Lengeler, C., Maude, G. H., Armah, G. E., Kajihara, B., Adiamah, J. H. \& Smith, P. G. (1996). Impact of permethrin impregnated bednets on child mortality in Kassena-Nankana district, Ghana: a randomized controlled trial. Tropical Medicine and Intermational Health, 1, 147-154.

Cartwright, K. (1995). Meningococcal carriage and disease. In: Meningococcal Disease, Cartwright, K. (editor). Chichester: John Wiley \& Sons, pp. 115-146.

Cartwright, K. A. V., Jones, D. M., Smith, A. J., Stuart, J. M Kaczmarski, E. B. \& Palmer, S. R. (1991). Influenza A and meningococcal disease. Lancet, 338, 554-557.

Cookson, S. T., Corrales, J. L., Lotero, J. O., Regueira, M., Binsztein, N., Reeves, M. W., Ajello, G. \& Jarvis, W. R. (1998). Disco fever: epidemic meningococcal disease in northeastern Argentina associated with disco patronage. Foumal of Infectious Diseases, 178, 266-269.

Enos, K. (1997). Cerebrospinal meningitis in northern Ghana: the experience of the War Memorial Hospital, Navrongo [Report]. Ghana: Ministry of Health.

Fischer, M., Hedberg, K., Cardosi, P., Plikaytis, B. D., Hoesly, F. C., Steingart, K. R., Bell, T. A., Fleming, D. W., Wenger, J. D. \& Perkins, B. A. (1997). Tobacco smoke as a risk factor for meningococcal disease. Pediatric Infectious Disease fournal, 16, 979-983.

Gagneux, S., Hodgson, A., Ehrhard, I., Morelli, G., Genton, B., Smith, T., Tanner, M., Binka, F., Achtman, M. \& Pluschke, G. (2000). Microheterogeneity of serogroup A 
(subgroup III) Neisseria meningitidis during an outbreak in northern Ghana. Tropical Medicine and International Health, $5,280-287$.

Greenwood, B. M., Bradley, A. K., Cleland, P. G., Haggie, M. H. K., Hassan-King, M., Lewis, L. S., Macfarlane, J. T., Taqi, A., Whittle, H. C., Bradley-Moore, A. M. \& Ansari, Q. (1979). An epidemic of meningococcal infection at Zaria, Northern Nigeria. 1. General epidemiological features. Transactions of the Royal Society of Tropical Medicine and Hygiene, 73, 557-562.

Greenwood, B. M., Bradley, A. K. \& Wall, R. A. (1985). Meningococcal disease and season in sub-Saharan Africa. Lancet, ii, 829-830.

Greenwood, B. M., Greenwood, A. M., Bradley, A. K, Williams, K., Hassan-King, M., Shenton, F. C., Wall, R. A. \& Hayes, R. J. (1987). Factors influencing susceptibility to meningococcal disease during an epidemic in The Gambia, West Africa. Foumal of Infection, 14, 167-184.

Haneberg, B., Tonjum, T., Rodahl, K. \& Gedde-Dahl, T. W. (1983). Factors preceding the onset of meningococcal disease, with special emphasis on passive smoking, stressful events, physical fitness and general symptoms of ill health. NIPH Annals, 6, 169-173.

Harrison, L. H., Armstrong, C. W., Jenkins, S. R., Harmon, M. W., Ajello, G. W., Miller, G. B. Jr \& Broom, C. V. (1991). A cluster of meningococcal disease on a school bus following epidemic influenza. Archives of Internal Medicine, 151, 1005-1009.

Hodgson, A., Smith, T., Gagneux, S., Akumah, I., Adjuik, M., Pluschke, G., Binka, F. \& Genton, B. (2001). Survival and sequelae of meningococcal meningitis in Ghana. International fournal of Epidemiology (in press).

Moodley, J. R., Coetzee, N. \& Hussey, G. (1999). Risk factors for meningococcal disease in Cape Town. South African Medical Foumal, 89, 56-59.

Moore, P.S. (1992). Meningococcal meningitis in sub-Saharan Africa: a model for the epidemic process. Clinical Infectious Diseases, 14, 515-525.

Pinner, R. W., Onyango, F., Perkins, B. A., Mirza, N. B., Ngacha, D. M., Reeves, M., DeWitt, W., Njeru, E., Agata, N. N., Broome, C.V. \& the Kenya/Centers for Disease Control (CDC) Meningitis Study Group (1992). Epidemic meningococcal disease in Nairobi, Kenya, 1989. Foumal of Infectious Diseases, 166, 359-364.

Salmi, I., Pettay, O., Simula, I., Kallio, A.-K. \& Waltimo, O. (1976). An epidemic due to sulphonamide-resistant group A meningococci in the Helsinki Area (Finland). Epidemiological and clinical observations. Scandinavian foumal of Infectious Diseases, 8, 249-254.

Stanwell-Smith, R. E., Stuart, J. M., Hughs, A. O., Robinson, P., Griffin, M. B. \& Cartwright, K. (1994). Smoking, the environment and meningococcal disease: a case control study. Epidemiology and Infection, 112, 315-328.

Tikhomirov, E., Santamaria, M. \& Esteves, K. (1997). Meningococcal disease: public health burden and control. World Health Statistics Quarterly, 50, 170-177.

Received 14 September 2000; revised 5 April 2001; accepted for publication 5 April 2001

\section{Announcement}

\section{ROYAL SOCIETY OF TROPICAL MEDICINE AND HYGIENE \\ Prizes}

\section{Undergraduate Project Prize}

The Royal Society of Tropical Medicine and Hygiene offers an annual prize of $£, 500$ for an account of work carried out of relevance to a tropical or developing country by a non-medical student of any nationality. The work (which may be laboratory-based and not necessarily carried out in a tropical or developing country) will add to the knowledge of human or veterinary health or hygiene in the tropics. Particular attention will be directed towards originality and quality in the award of the prize. It is anticipated that the prize will act as a stimulus for the pursuit of excellence in research carried out by undergraduates.

\section{Medical Student Elective Prize}

The Royal Society of Tropical Medicine and Hygiene offers an annual prize of $£ 500$ for an account of work carried out by a medical student of any nationality during an elective period spent in a tropical or developing country. In awarding this prize emphasis will be laid on the originality of the work and on its contribution to knowledge or understanding of tropical diseases. Particular weight will be given to projects which have been developed and carried out by the students themselves.

\section{Rules}

1. Two prizes of $£ 500$ may be awarded annually in recognition of outstanding projects which increase knowledge of tropical medicine and hygiene in the broadest sense. Abstracts of the winning reports will be published in the Transactions.

2. Candidates shall be nominated by their head of department, supervisor or Dean, with a supporting statement of up to 500 words.

3. The closing date for receipt of project reports is 31 December. The project should have been done or completed in the previous twelve months.

4. A committee of three shall choose the prize winners.

5. The announcement of the prize winners will be made at the March meeting of the Society.

6. The prizes will be presented by the President of the Society at the Annual General Meeting in June or July.

Please note that the Society cannot provide funds to cover students' elective travel expenses.

Application forms may be obtained from the Administrator, Royal Society of Tropical Medicine and Hygiene, Manson House, 26 Portland Place, London, W1B 1EY, UK; fax +44 (0)20 7436 1389, e-mail mail@rstmh.org 